\title{
IMPACT OF FEED MIXTURE ON KINETIC STRENGTH OF PELLETS FOR POULTRY
}

\begin{tabular}{|c|c|}
\hline \multicolumn{2}{|c|}{$\begin{array}{l}\text { Institute of Machinery Management, Ergonomics and Production Processes, University of Agriculture } \\
\text { in Krakow }\end{array}$} \\
\hline \multicolumn{2}{|c|}{${ }^{*}$ Corresponding author: e-mail: zygmunt.sobol@ur.krakow.pl } \\
\hline ARTICLE INFO & ABSTRACT \\
\hline $\begin{array}{l}\text { Article history: } \\
\text { Received: March } 2017 \\
\text { Received in the revised form: } \\
\text { May } 2017 \\
\text { Accepted: June } 2017\end{array}$ & $\begin{array}{l}\text { The paper presents the impact of feed mixtures for poultry on their } \\
\text { kinetic strength determined with Holmen's method. Research material } \\
\text { came from a production line and } 9 \text { pelleted feed mixtures for poultry } \\
\text { with diameter of } 3.2 \mathrm{~mm} \text { were accepted for the research. Feed was } \\
\text { prepared, pelleted and cooled with the use of the same devices and }\end{array}$ \\
\hline $\begin{array}{l}\text { Key words: } \\
\text { feed, } \\
\text { pellet, } \\
\text { raw material, } \\
\text { kinetic strenght }\end{array}$ & $\begin{array}{l}\text { their exploitation settings were comparable with regard to the investi- } \\
\text { gated feed pellet. The obtained research results proved that kinetic } \\
\text { strength of the investigated feed pellets was statistically significant in } \\
\text { relation to the composition of the feed mixture. Relations of kinetic } \\
\text { strength of pellets to the composition of the feed mixtures were deter- } \\
\text { mined with the multiple regression method. From the determined } \\
\text { models the highest utilitarian value may occur in case of a model with } \\
\text { four explanatory variables: corn }\left(\mathrm{x}_{1}\right) \text {, wheat }\left(\mathrm{x}_{2}\right) \text {, soya meal }\left(\mathrm{x}_{4}\right) \text { and } \\
\text { fat }\left(\mathrm{x}_{5}\right) \text {. }\end{array}$ \\
\hline
\end{tabular}

\section{Introduction}

Many researchers confirm in a multi-trend evaluation, the prevailance of the pelleted feed quality over loose feed (Grochowicz, 1996; Thomas et al., 1997; Walczyński et al., 2000; Rynkiewicz, 2008; Obidziński and Hejft, 2012). Pelleted feed used in the feeding process is defined by: a higher nutritional value, uniformity of structure, no layering, better taste, lower content of bacteria and funghi, longer shell life and the fact that animals eagerly eat it. However, one of the most important quality features of the pellteted feed is their kinetic strength (Grochowicz, 1996; Rynkiewicz, 2008; Kulig and Laskowski, 2006; Obidziński, 2014; Zawiślak et al., 2010). High kinetic strength decides whether the feed will be more endurable and it means that pellets are minimally damaged during transport, storage and feeding. High quality of pellets related to kinetic strength results most often from:

- material composition of a mixture including fat content, fragmentation degree and uniformity of the mixture (Thomas et al., 1998; Walczyński et al., 2000; Walczyński and Zawiślak, 2000; Kulig and Laskowski, 2006; Rynkiewicz, 2008; Zawiślak et al., 2010),

- methods of preparation of a mixture for pelletization and pelletization and cooling method (Kulig and Laskowski, 2005; Rynkiewicz, 2007; Zawiślak et al., 2010),

- structures of working units and their setting parameters (Zawiślak 2006; Obidziński and Hejft, 2012, 2013). 
When selecting a raw material composition of the mixture a compromise is made between its nutritional properties and susceptibility of particular components to pelletization. Kinetic strength of pellets is determined with reference to two types of forces:

- dynamic, which the most often are active during transport,

- statical, which load pellets during storage.

According to Obidziński (2014) kinetic strength of feed pellet is investigated with the following methods:

- "Handling system",

- by Schatter,

- Pfost,

- modified by Pfost,

- by Holmen.

On the other hand, hardness of pellet (Marks et al., 2006; Obidziński, 2014) may be determined with:

- Kahl's hardness tester,

- Schleuniger's tester,

- swing tester,

- with the use of strength machine e.g. Instron,

- Kramer's apparatus,

- spring static penetrometer.

The objective of the research was to determine the composition of feed mixtures for poultry on the kinetic strength of pellet which was investigated with Holmen's method.

\section{Material and methods}

Material for the research came from a production line which produced poultry feed. Pelletization was made on Sprout-Matador PM12K pelleting machine. 9 pelleted feed mixtures for poultry with a diameter of pellets $3.2 \mathrm{~mm}$ were used for the research. Conditioning of the mixture took place in the conditioner of a pelleting machine and lasted $12015 \mathrm{~s}$ at the pressure of steam of 1.8-2.4 at. Pellets were cooled in the column cooler Geelen Counterflow VK - KL Cooling time of pellets was 6-8 min. Moisture after cooling of the investigated pellets was within $10.9 \%$ to $13.6 \%$.

A working unit comprised the driven vertical ring matrix with a diameter of $615 \mathrm{~mm}$. A matrix with the width of the working surface of $150 \mathrm{~mm}$ had calibrating openings with the diameter of $3.2 \mathrm{~mm}$ and length $74 \mathrm{~mm}$. 3 pressing rolls cooperated with the matrix. Working surfaces of roller sleeves were shaped as conical hollows.

Kinetic strength tests of pellets were carried out with the use of Holmen's NHM 100 apparatus. Material for research after the last production stage i.e. cooling was set aside for 24 hours in order to stabilize internal stresses. After that time, pellets were subjected to strength test. A sample for research was sieved through a sieve with dimension of meshes of $2.8 \mathrm{~mm}$. From the siftings a sample of $100 \mathrm{~g}$ of pellets was placed in the tester chamber. A sample in the tester circulated in the forced air stream for $60 \mathrm{~s}$ hitting, among others, a steel obstacle. Firstly the sample then its part which stayed on the device sieve were weighted. Kinetic strength index $\mathrm{P}_{\mathrm{dx}}$ was expressed with the relation of siftings remaining 
Impact of feed mixture...

on a sieve of the device to the sample mass $(100 \mathrm{~g})$ introduced to the tester (Obidziński, 2014). Kinetic strength of pellets was tested in 10 iterations for each investigated feed mixture. Statistical analyses were carried out with the use of Statistica 12 program.

\section{Results and discussion}

Composition of feed mixtures used in the experiment was presented in table 1. For statistical analyses of the impact of the raw material composition on kinetic strength of feed pellets, those elements were accepted which the most often occurred in the investigated pellets i.e. corn, wheat, rape cake, soya meal and fat.

Table 1.

Composition of the investigated poultry feed mixtures

\begin{tabular}{|c|c|c|c|c|c|c|c|c|c|c|c|}
\hline \multirow[b]{2}{*}{$\begin{array}{l}\text { Type } \\
\text { of } \\
\text { feed }\end{array}$} & \multirow[b]{2}{*}{ Product } & \multicolumn{10}{|c|}{ Element, } \\
\hline & & 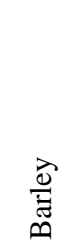 & छั & $\frac{\pi}{\pi}$ & 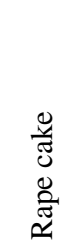 & 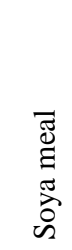 & 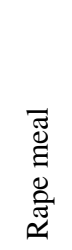 & 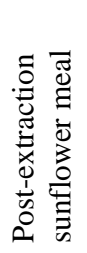 & 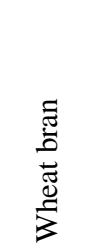 & $\underset{\pi}{\vec{T}}$ & 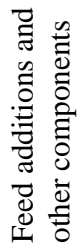 \\
\hline BFP & Brojler Finiszer Prestiż & 0.00 & 15.20 & 49.97 & 7.00 & 19.25 & 0.00 & 0.00 & 0.00 & 5.85 & 2.73 \\
\hline BFPA & Brojler Finiszer Prestiż A-Cox & 0.00 & 11.35 & 54.90 & 7.00 & 18.20 & 0.00 & 0.00 & 0.00 & 5.75 & 2.80 \\
\hline BFPG & Brojler Finiszer Prestiż G & 0.00 & 16.35 & 49.89 & 7.00 & 18.30 & 0.00 & 0.00 & 0.00 & 6.80 & 1.66 \\
\hline BG1P & Brojler Grower1 Prestiż & 0.00 & 15.00 & 49.53 & 4.00 & 23.30 & 0.00 & 0.00 & 0.00 & 3.35 & 4.82 \\
\hline BG2P & Brojler Grower2 Prestiż & 0.00 & 15.00 & 47.56 & 6.00 & 22.61 & 0.00 & 0.00 & 0.00 & 5.44 & 3.39 \\
\hline BSP & $\begin{array}{l}\text { Brojler Starter } \\
\text { Prestiż }\end{array}$ & 0.00 & 20.00 & 42.69 & 3.00 & 24.61 & 0.00 & 0.00 & 0.00 & 2.69 & 7.01 \\
\hline EK1 & Efekt Kurka 1 B/K & 5.00 & 15.00 & 52.70 & 0.00 & 4.40 & 7.00 & 9.50 & 2.50 & 0.50 & 3.40 \\
\hline EK2 & Efekt Kurka 2 B/K & 6.50 & 20.00 & 38.94 & 0.00 & 1.00 & 7.00 & 5.00 & 15.00 & 0.50 & 6.06 \\
\hline KR1 & Kurka R-1 PLUS & 5.00 & 15.00 & 52.32 & 0.00 & 5.30 & 7.00 & 9.00 & 2.50 & 0.50 & 3.38 \\
\hline
\end{tabular}


Analysis of the investigated feed mixtures proves the highest participation of:

- corn for BSP and EK1 - 20\% each.

- wheat for BFPA - 54.90 \%, EK1 - 52.70\% and KR1 - 52.32\%.

- rape cake for BFP, BFPA and BFPG - 7\% each.

- soya meal for BSP - 24.61\% and BG1P - 23.30\%.

- fat for BFG - $6.80 \%$ and BFP - 5.85\%.

The lowest participation of particular components was reported for:

- corn BFPA - $11.35 \%$,

- wheat EK2 - 38.94\%,

- soya meal EK2 - $1.00 \%$,

- fat EK1, EK2, KR1 - 0.50\% each.

Kolmogorov-Smirnov test proved regularity of the distribution of kinetic strength for the investigated pelleted feed. The investigated distributions had uniform variations which were checked with Levene's test. The analysis of variance in a single classification proved statistically significant differences in kinetic strength of feed pellet in relation to the composition of feed mixture (Table 2). Kinetic strength within the investigated feed was within $77.10 \%$ for BFPG to $93.73 \%$ EK2 (Figure 1). Based on Duncan's test (Table 3) it was found out that on account of kinetic strength the following uniform groups were determined: 1st group Brojler Finiszer Prestiż G (BFPG), Brojler Finiszer Prestiż (BFP); 2nd group- Brojler Grower2 Prestiż (BG2P), Brojler Starter Prestiż (BSP), Brojler Grower1 Prestiż (BG1P), Brojler Finiszer Prestiż A-Cox (BFPA); 3rd group - Kurka R-1 PLUS (KR1), Efekt Kurka 1 B/K (EK1) and 4th group - Efekt Kurka 2 B/K (EK2). From the obtained values of kinetic strength of the investigated feed pellets two feeds i.e. of the 1st uniform group (Table 3) may be qualified according to Walczyń (1997) as unsatisfactory with regard to strength $\left(\mathrm{P}_{\mathrm{dx}}\right.$ less than $\left.80 \%\right)$. Feed from the 2nd group should be qualified as pellets with satisfactory strenght and from group 3 and 4 as high quality pellets (Walczyński, 1997).

Table 2.

Analysis of variance in single classification. Impact of the feed type on kinetic strength of pellets

\begin{tabular}{ccccc}
\hline Effect & $\begin{array}{c}\text { Freedom } \\
\text { degrees }\end{array}$ & Mean square & Test F & $\begin{array}{c}\text { The obtained } \\
\text { level p }\end{array}$ \\
\hline Feed type & 8 & 283.9 & 26.78 & 0.0000 \\
\hline
\end{tabular}


Impact of feed mixture...

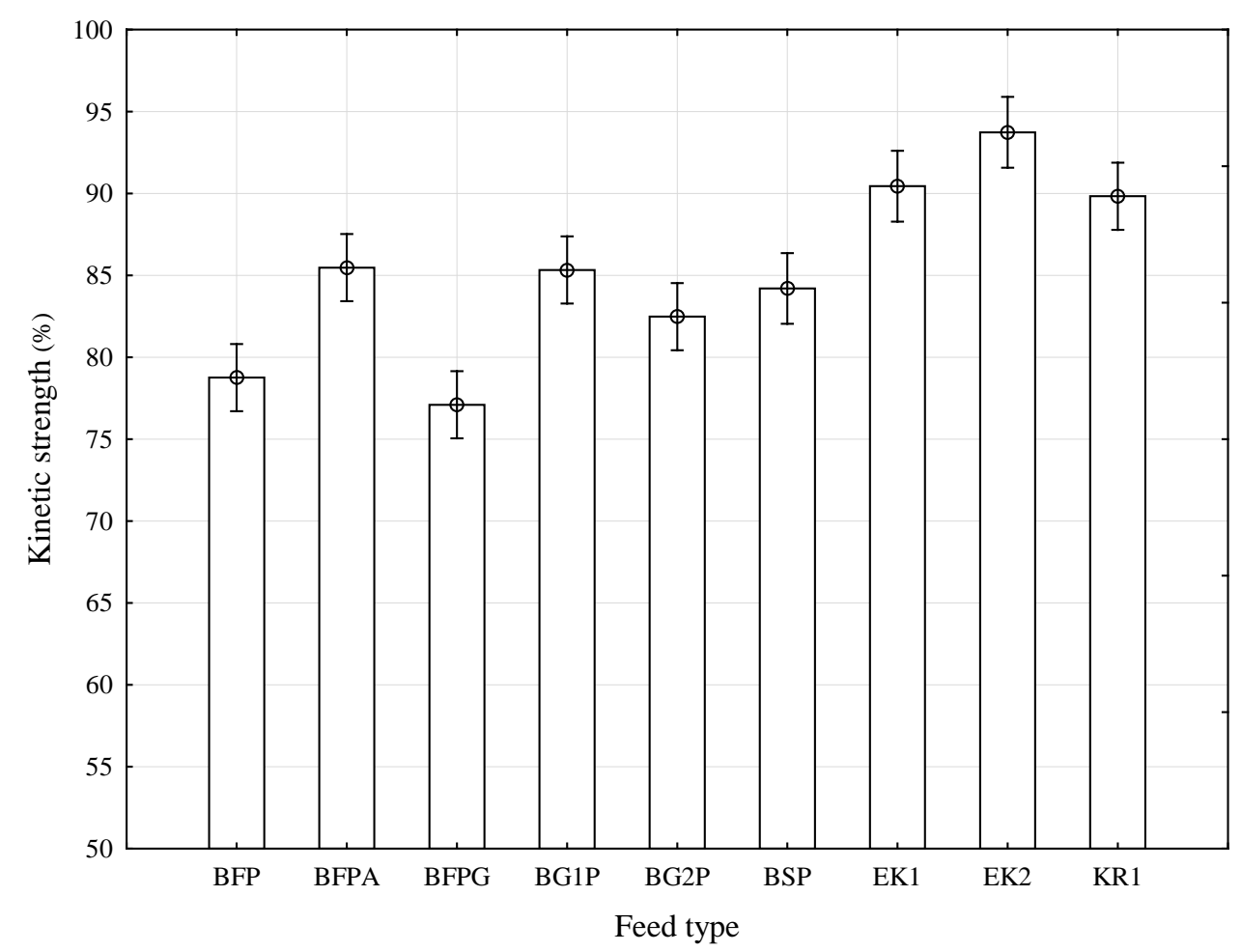

Figure 1. Impact of feed type on kinetic strength of pellets

Table 3.

Duncan test results for kinetic strength of pellets Uniform groups for the feed type

\begin{tabular}{|c|c|c|c|c|c|}
\hline Feed type & $\begin{array}{l}\text { Kinetic strength (\%) } \\
\text { Average }\end{array}$ & 1 & 2 & 3 & 4 \\
\hline BFPG & 77.10 & $* * * *$ & & & \\
\hline BFP & 78.76 & $* * * *$ & & & \\
\hline BG2P & 82.48 & & $* * * *$ & & \\
\hline BSP & 84.20 & & $* * * *$ & & \\
\hline BG1P & 85.33 & & $* * * *$ & & \\
\hline BFPA & 85.47 & & $* * * *$ & & \\
\hline KR1 & 89.83 & & & $* * * *$ & \\
\hline EK1 & 90.44 & & & $* * * *$ & \\
\hline EK2 & 93.73 & & & & $* * * *$ \\
\hline
\end{tabular}


Relations of kinetic strength of pellets to the composition of the feed mixtures were determined with the multiple regression method (Table 4). Percentage shares of particular elements in the mixture were determined: corn $\left(\mathrm{x}_{1}\right)$, wheat $\left(\mathrm{x}_{2}\right)$, rape cake $\left(\mathrm{x}_{3}\right)$, soya meal $\left(\mathrm{x}_{4}\right)$ and fat $\left(\mathrm{x}_{5}\right)$.

For determination of models analyses for the entire collection of data (90 cases) were carried out. In the group:

- with one explanatory variable the highest participation of explained variation $\left(\mathrm{R}^{2}=59.36 \%\right)$ was obtained for model with a variable 'fat' $\left(\mathrm{x}_{5}\right)$,

- with two variables the best reflection of changes of kinetic strength of pellets $\left(\mathrm{R}^{2}=61.72 \%\right)$ was reported for variables 'corn' $\left(\mathrm{x}_{1}\right)$ and 'fat' $\left(\mathrm{x}_{5}\right)$,

- with three explanatory variables the highest participation of explained variation $\left(\mathrm{R}^{2}=69.76 \%\right)$ was obtained after introduction to the model the following variables corn $\left(\mathrm{x}_{1}\right)$, wheat $\left(\mathrm{x}_{2}\right)$ and rape cake $\left(\mathrm{x}_{3}\right)$,

- with four explanatory variables the highest participation of explained variation $\left(\mathrm{R}^{2}=70.56 \%\right)$ was obtained for a model, where the following variables were included: corn $\left(\mathrm{x}_{1}\right)$, wheat $\left(\mathrm{x}_{2}\right)$, soya meal $\left(\mathrm{x}_{4}\right)$ and fat $\left(\mathrm{x}_{5}\right)$,

- with five explanatory variables a compliance of the model with experimental data on a similar level was obtained $\left(\mathrm{R}^{2}=70.56 \%\right)$ which with four independent variables.

From the determined models the highest utilitarian value may occur in case of a model with four explanatory variables: corn $\left(\mathrm{x}_{1}\right)$, wheat $\left(\mathrm{x}_{2}\right)$, soya meal $\left(\mathrm{x}_{4}\right)$ and fat $\left(\mathrm{x}_{5}\right)$.

Table 4.

Results of estimation of model parameters

\begin{tabular}{|c|c|c|c|c|c|c|c|c|}
\hline \multirow[b]{2}{*}{ Item } & \multirow{2}{*}{ 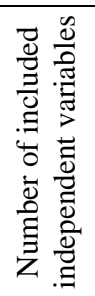 } & \multicolumn{6}{|c|}{$\mathrm{y}=\mathrm{a}+\mathrm{b} \cdot \mathrm{x}_{1}+\mathrm{c} \cdot \mathrm{x}_{2}+\mathrm{d} \cdot \mathrm{x}_{3}+\mathrm{e} \cdot \mathrm{x}_{4}+\mathrm{f} \cdot \mathrm{x}_{5}$} & \multirow{2}{*}{$\begin{array}{c}\text { Participation } \\
\text { of explained } \\
\text { variation } \mathrm{R}^{2} \\
\quad(\%)\end{array}$} \\
\hline & & $\begin{array}{c}\mathrm{a} \\
(-)\end{array}$ & $\begin{array}{c}\text { b } \\
(-)\end{array}$ & $\begin{array}{c}\text { C } \\
(-)\end{array}$ & $\begin{array}{c}\mathrm{d} \\
(-)\end{array}$ & $\begin{array}{c}\mathrm{e} \\
(-)\end{array}$ & $\begin{array}{c}\mathrm{f} \\
(-)\end{array}$ & \\
\hline 1 & 1 & 78.9763 & $0.3888 *$ & $\longrightarrow$ & - & - & - & 2.67 \\
\hline 2 & 1 & 97.1964 & - & $\begin{array}{c}- \\
0.2473 *\end{array}$ & 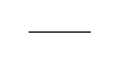 & 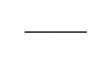 & 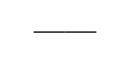 & 3.73 \\
\hline 3 & 1 & 90.9629 & - & - & -1.5094 & - & - & 56.30 \\
\hline 4 & 1 & 92.1692 & - & - & - & -0.4580 & - & 41.94 \\
\hline 5 & 1 & 91.8842 & - & - & - & - & -1.8988 & 59.36 \\
\hline 6 & 2 & 104.534 & $-0.1844 *$ & $\begin{array}{c}- \\
0.3378 *\end{array}$ & 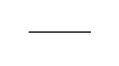 & ـ & - & 3.83 \\
\hline 7 & 2 & 99.0332 & -0.4690 & - & -1.6805 & $\longrightarrow$ & - & 59.46 \\
\hline 8 & 2 & 89.6810 & $0.1507^{*}$ & - & - & -0.4510 & - & 42.33 \\
\hline 9 & 2 & 98.7489 & -0.3979 & - & - & - & -2.0616 & 61.72 \\
\hline 10 & 2 & 89.0759 & - & $0.0401 *$ & -1.5280 & 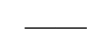 & - & 56.39 \\
\hline
\end{tabular}


Impact of feed mixture...

\begin{tabular}{|c|c|c|c|c|c|c|c|c|}
\hline \multirow[b]{2}{*}{ Item } & \multirow{2}{*}{ 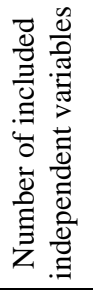 } & \multicolumn{6}{|c|}{$\mathrm{y}=\mathrm{a}+\mathrm{b} \cdot \mathrm{x}_{1}+\mathrm{c} \cdot \mathrm{x}_{2}+\mathrm{d} \cdot \mathrm{x}_{3}+\mathrm{e} \cdot \mathrm{x}_{4}+f \cdot \mathrm{x}_{5}$} & \multirow{2}{*}{$\begin{array}{c}\text { Participation } \\
\text { of explained } \\
\text { variation } \mathrm{R}^{2} \\
\text { (\%) }\end{array}$} \\
\hline & & $\begin{array}{c}\mathrm{a} \\
(-)\end{array}$ & $\begin{array}{c}\mathrm{b} \\
(-)\end{array}$ & $\begin{array}{c}\text { C } \\
(-)\end{array}$ & $\begin{array}{c}\mathrm{d} \\
(-)\end{array}$ & $\begin{array}{c}\mathrm{e} \\
(-)\end{array}$ & $\begin{array}{c}\mathrm{f} \\
(-)\end{array}$ & \\
\hline 11 & 2 & 101.2750 & $\bar{L}$ & $0.1887^{-} *$ & - & -0.4505 & $\longrightarrow$ & 44.10 \\
\hline 12 & 2 & 90.3997 & $\longrightarrow$ & 0.0316* & $\longrightarrow$ & $\longrightarrow$ & -1.9158 & 59.42 \\
\hline 13 & 2 & 91.8364 & 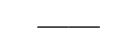 & - & -1.2366 & $-0.1253 *$ & $\longrightarrow$ & 57.60 \\
\hline 14 & 2 & 92.6545 & 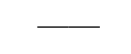 & - & $1.6855^{*}$ & - & -3.9465 & 60.52 \\
\hline 15 & 2 & 92.6959 & - & - & - & $-0.1284 *$ & -1.5720 & 60.90 \\
\hline 16 & 3 & 180.4219 & -2.3425 & -1.0445 & -1.8791 & - & - & 69.76 \\
\hline 17 & 3 & 144.0995 & -1.0696 & -0.7103 & 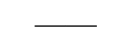 & -0.4798 & - & 47.30 \\
\hline 18 & 3 & 168.2020 & -1.9829 & -0.8971 & - & - & -2.2265 & 69.53 \\
\hline 19 & 3 & 98.6387 & -0.4163 & $\longrightarrow$ & -1.5011 & $-0.0736 *$ & $\longrightarrow$ & 59.87 \\
\hline 20 & 3 & 98.2545 & $-0.3431^{*}$ & $\longrightarrow$ & $0.9875 *$ & - & -3.2390 & 62.08 \\
\hline 21 & 3 & 98.4762 & $-0.3457 *$ & - & - & $-0.0993 *$ & -1.7875 & 62.60 \\
\hline 22 & 3 & 92.7910 & & $\begin{array}{c}- \\
0.0020 *\end{array}$ & - & $-0.1287^{*}$ & -1.5701 & 60.90 \\
\hline 23 & 3 & 91.7466 & & 0.0019* & -1.2383 & $-0.1250 *$ & $\longrightarrow$ & 57.60 \\
\hline 24 & 3 & 92.1118 & - & $0.0114^{*}$ & $1.6664 *$ & $\bar{T}$ & -3.9294 & 60.53 \\
\hline 25 & 3 & 94.8326 & - & - & 3.2863 & -0.2288 & -5.3090 & 64.35 \\
\hline 26 & 4 & 179.4960 & -2.2891 & -1.0363 & -1.7458 & $-0.0540 *$ & $\longrightarrow$ & 69.98 \\
\hline 27 & 4 & 175.9059 & -2.2093 & -0.9892 & $-1.1471^{*}$ & - & $-0.8759 *$ & 69.92 \\
\hline 28 & 4 & 168.6301 & -1.9428 & -0.9065 & - & $-0.1079 *$ & -1.9304 & 70.56 \\
\hline 29 & 4 & 96.7647 & $-0.1328 *$ & - & 2.8434 & -0.2041 & -4.8881 & 64.54 \\
\hline 30 & 4 & 98.6849 & $\bar{L}$ & $\begin{array}{c}- \\
0.0767 * \\
\end{array}$ & 3.5577 & -0.2491 & -5.5455 & 64.65 \\
\hline 31 & 5 & 168.4690 & -1.9376 & -0.9046 & $0.0245^{*}$ & $-0.1087^{*}$ & $-1.9568 *$ & 70.56 \\
\hline
\end{tabular}

* statistically insignificant regression coefficient

- variable not included in the model

Analysis of the obtained research results (Table 4) concerning the impact of particular components of feed mixtures confirms destructive impact for kinetic strength of fat introduced directly $\left(\mathrm{x}_{5}\right)$ and indirectly in the form of soya meal $\left(\mathrm{x}_{4}\right)$. The obtained research 
results are compliant with the research carried out by Kulig and Laskowski (2005). On the other hand, the impact of wheat components (including fiber) on kinetic strength was documented with a considerably high level of strength of the investigated feed. Slight variability of the impact on the kinetic strength of pellets, wheat $\left(\mathrm{x}_{2}\right)$ contrary to the research by Kulig and Laskowski (2005) and corn (x1) may result from a low variability of these components in the investigated feed.

\section{Conclusions}

1. Kinetic strength of the investigated pelleted feed with values within $77.10-93.73 \%$ was statistically significant in relation to the feed type.

2. Out of nine investigated feeds only two (BFPG $-77.10 \%$ and BFP $-78.76 \%$ ) were qualified as pelleted feed with kinetic strength lower than satisfactory (below 80.00\%).

3. The lowest kinetic strength was reported for feed KR1 (89.82\%), EK1 (90.44\%) and eK2 (93.73\%).

4. 31 models were determined with the use of multiple regression, out of which 24 obtained the participation of explained variation above 50\%.

5. The highest utilitarian value was reported in case of the model with four explanatory variables: corn $\left(\mathrm{x}_{1}\right)$, wheat $\left(\mathrm{x}_{2}\right)$, soya meal $\left(\mathrm{x}_{4}\right)$ and fat $\left(\mathrm{x}_{5}\right)$.

\section{References}

Grochowicz, J. (1996). Technologia produkcji mieszanek paszowych. PWRiL, Warszawa.

Kulig, R., Laskowski, J. (2005). Wpływ procesu kondycjonowania surowców zbożowych na wybrane właściwości fizyczne granulatu. Acta Agrophysica, 5(2), 325-334.

Kulig, R., Laskowski, J. (2006). Wpływ wybranych właściwości surowców na cechy wytrzymałościowe granulatu. Inżynieria Rolnicza, 13, 251-260.

Marks, N., Sobol, Z., Baran, D. (2006). Ocena wytrzymałości granulatu paszowego. Inżynieria Rolnicza, 3, 289-296.

Obidziński, S. (2014). Badania porównawcze metod oceny wytrzymałości kinetycznej granulatu Inżynieria Przetwórstwa Spożywczego, 2/4(10), 26-29.

Obidziński, S., Hejft, R. (2012). Wpływ parametrów techniczno-technologicznych procesu granulowania pasz na jakość otrzymanego produktu. Journal of Research and Applications in Agricultural Engineering, 57(1), 109-114.

Obidziński, S., Hejft, R. (2013). Dobór parametrów techniczno-technologicznych procesu granulowania odpadów roślinnych. Inżynieria Aparatura Chemiczna, 53, 3, 210-212.

Rynkiewicz, M. (2007). Ocena wpływu temperatury chłodzenia na wytrzymałość kinetyczną granul. Inżynieria Rolnicza, 6(94), 223-229.

Rynkiewicz, M. (2008). Wpływ stopnia rozdrobnienia granulowanej mieszanki paszowej na wytrzymałość kinetyczną granul i wydajność produkcji zwierzęcej. Inżynieria Rolnicza, 5(103). 229-235.

Thomas, M., van der Vliet, T., Poel, A.F.B. (1998). Physical quality of pelleted animal feed. 3. Contribution of feedstuff components. Animal Feed Science Technology, 71, 59-78.

Thomas, M., van Zuilichem, D.J., van der Poel, A.F.B. (1997). Physical quality of pelleted animal feed. 2. Contribution of processes and its conditions. Animal Feed Science Technology, 64, 173-192.

Walczyński, S. (1997). Porównanie metod oznaczania wytrzymałości kinetycznej granulatów. Pasze Przemystowe, 11-12, 17-19. 
Impact of feed mixture...

Walczyński, S., Zawiślak, K. (2000). Wpływ dodatku thuszczu na jakość granul w procesie aglomeracji bez dodatku pary. Pasze Przemystowe 4/5, 17-19.

Walczyński, S., Zawiślak, K., Podgórska, H. (2000). Wpływ składu mieszanek paszowych i metod granulowania na jakość granulatu. Biuletyn Naukowy Przemystu Paszowego, 3-4, 67-78.

Zawiślak, K. (2006). Wpływ kształtu powierzchni rolek wytłaczających na trwałość granulatu. Inżynieria Rolnicza, 7(82), 475-483.

Zawiślak, K., Sobczak, P., Panasiewicz, M. Markowska, A. (2010). Wpływ wybranych parametrów technologicznych na wytrzymałość kinetyczną granulatu. Acta Scientiarum Polonorum, Technica Agraria, 9(1-2), 3-10.

\section{WPLYW SKLADU MIESZANKI PASZOWEJ NA WYTRZYMAŁOŚĆ KINETYCZNĄ GRANULATU DLA DROBIU}

Streszczenie. W pracy przeanalizowano wpływ składu mieszanek paszowych dla drobiu, na ich wytrzymałość kinetyczną, określaną metodą Holmena. Materiał do badań pochodził z linii produkcyjnej, a do analizy przyjęto 9 granulowanych mieszanek paszowych dla drobiu o średnicy granul 3,2 mm. Paszę przygotowywano, granulowano i schładzano wykorzystując te same urządzenia, a ich nastawy eksploatacyjne były porównywalne w odniesieniu do badanego granulatu paszowego. Uzyskane wyniki badań wykazały, że wytrzymałość kinetyczna badanych granulatów paszowych była statystycznie istotna $\mathrm{w}$ zależności od składu mieszanki paszowej. Zależności wytrzymałości kinetycznej granulatu od składu mieszanek paszowych wyznaczono metodą regresji wielorakiej. Z wyznaczonych modeli największą wartość utylitarną może mieć model z czterema zmiennymi objaśniającymi: kukurydza $\left(\mathrm{x}_{1}\right)$, pszenica $\left(\mathrm{x}_{2}\right)$, śruta sojowa $\left(\mathrm{x}_{4}\right)$ oraz thuszcz $\left(\mathrm{x}_{5}\right)$.

Słowa kluczowe: pasze, granulat, surowce, wytrzymałość kinetyczna 